\title{
Muséologies
}

Les cahiers d'études supérieures

\section{Moving (in) the museum}

\section{Re-enactment as research into the musealization of dance}

\section{Timmy De Laet}

Volume 8, numéro 1, 2015

Réflexions sur la pratique curatoriale et la recherche-création

URI : https://id.erudit.org/iderudit/1034610ar

DOI : https://doi.org/10.7202/1034610ar

Aller au sommaire du numéro

Éditeur(s)

Association Québécoise de Promotion des Recherches Étudiantes en Muséologie (AQPREM)

ISSN

1718-5181 (imprimé)

1929-7815 (numérique)

Découvrir la revue

Citer cet article

De Laet, T. (2015). Moving (in) the museum: Re-enactment as research into the musealization of dance. Muséologies, 8(1), 55-70.

https://doi.org/10.7202/1034610ar

Tous droits réservés (C Association Québécoise de Promotion des Recherches Étudiantes en Muséologie (AQPREM), 2016
Ce document est protégé par la loi sur le droit d'auteur. L'utilisation des services d'Érudit (y compris la reproduction) est assujettie à sa politique d'utilisation que vous pouvez consulter en ligne.

https://apropos.erudit.org/fr/usagers/politique-dutilisation/ 
Article deux

\section{Moving (in) the museum \\ Re-enactment as research into the musealization of dance \\ Timmy De Laet}


Timmy De Laet $\left({ }^{\circ} 1983\right)$ is a junior researcher at the Department of Theatre and Film Studies at the University of Antwerp and a member of the Research Centre for Visual Poetics. He had an actor training at the Royal Conservatoire of Antwerp, holds a Master's and an Advanced Master's Degree in Theatre Studies from the University of Antwerp, and studied Dance Theory at the Freie Universität Berlin. From 2009, he has been a Fellow of the Research Foundation Flanders (FWO). He is currently completing his $\mathrm{PhD}$ dissertation, titled "Re-inventing the Past. Re-enactment in Contemporary Dance and Performance Art". In 2011, he was awarded the Routledge Prize at the PSi\# 17 conference in Utrecht. Timmy.DeLaet@uantwerpen.be 


\section{Dance on Display}

In his book Profanations, the Italian philosopher Giorgio Agamben claimed that "everything today can become a Museum, because this term simply names the exposition of an impossibility of using, of dwelling, of experiencing" ${ }^{1}$. It is obvious that Agamben was thinking about the museum in its most stereotypical incarnations: as imperial and exclusionary fortresses that dispel life from between their walls and are primarily preoccupied with ensuring the preservation of the allegedly sacrosanct objects they house. What he did not seem to realize is that, around the time when he wrote this, the museum had already undergone various profound changes that would make his statement untenable. As a matter of fact, precisely the activities of using, dwelling, and experiencing have ever since become increasingly central to the workings of the museum. To mark these developments, Eileen Hooper-Greenhill proposes to speak of the "post-museum", which she defines in contrast to "the modernist museum [that] was (and is) imagined as a building" where collections are accumulated and displayed, while "the museum of the future may be imagined as a process or an experience" ${ }^{2}$. Indeed, fuelled by a desire to redefine their societal value, a growing number of contemporary museums have ventured to break down their institutional barriers, not only by engaging more directly with their public, but also by opening their doors to practices that had long been considered extraneous to their spaces.

One of the most recent eruptions of this tendency is the remarkable attempt, prompted by curators and artists alike, to find ways for contemporary dance to intrude into the museum.

1 AGAMBEN, Giorgio. Profanations. FORT, Jeff(Transl.). New York: Zone Books, 2007, p. 84, emphasis added. 2 HOOPER-GREENHILL, Eileen. Museums and the Interpretation of Visual Culture. London and New York: Routledge, 2000, p. 152. This profound reorientation of museal and curatorial practices is even approached as a paradigm shift in ANDERSON, Gail (Ed.). Reinventing the Museum. Historical and Contemporary Perspectives on the Paradigm Shift. Walnut Creek, California: Altamira Press, 2004

3 The lack of a clear-cut definition of "re-enactment" stems largely from the fact that, from the 1990 s onwards, the notion
This growing phenomenon signals a radical change of attitude. While it has arguably never been the intention of museums to deliberately exclude dance from their collections, there is no doubt either that sustained efforts to consciously include this art form in ways that also do justice to its proper mode of being have been scarce, if not inexistent. To be sure, more traditional means of representation (such as videos, photographs, or drawings) might have occasionally provided museum visitors with a glimpse of historical dance pieces, but the considerably more difficult endeavour to display these works as creations to be performed live has never been a topic of serious consideration. No matter whether this longstanding negligence was due to curatorial decisions or rather logistic reasons, the tide seems to be turning. More and more, museum visitors are likely to be confronted with live performers presenting choreographic works amidst the objects that usually make up the core of the museum's collection.

Coinciding with the heightened interest in establishing renewed affiliations between dance and museums is the notable ambition to develop innovative exhibition formats that not only facilitate the accommodation of choreographic works in museal settings but which often also aim to offer a different perspective of the pieces on display. Next to the perhaps more obvious option of juxtaposing the exhibited material with actual restagings of past choreographies, both artists and institutions are increasingly exploring various types of so-called "re-enactments" that take a more liberal approach and deliberately appropriate, re-interpret, or transform the pieces that would otherwise be kept intact. Taking into account that the exact meaning of the term "re-enactment" tends to vary widely ${ }^{3}$,

has been circulating widely in the art scene, referring to a vast variety of artistic projects that are, generally speaking, re-doings of historical events or existing art works. Together with the increased use of the term "re-enactment", its actual meaning tends to deflate, which, in turn, has led to a range of terminological discussions. Cf. MAIN, Lesley. "Reconstruction, Re-creation, Reinvention”. In. Directing the Dance Legacy of Doris Humphrey. The Creative Impulse of Reconstruction. Wisconsin: The University of Wisconsin Press, 2012, pp. 21-24. 
I explicitly understand it here as a re-interpretative strategy that instigates a larger artistic research into both the historicization and institutionalization of dance and other arts. On this ground, "re-enactment" can be distinguished from a more traditional practice of "re-staging" that encompasses rather literal and formal facsimiles of historical originals and which is primarily aimed at providing vivid representations of the past.

Applying this distinction to the appearance of dance in museums, examples of the latter kind include Centre Pompidou's major exhibition on dance, Danser sa vie $(2011)^{4}$, or the recent retrospective of Yvonne Rainer's early dance works at the Raven Row Gallery in London (2014). While the former featured a side-program with showings of Steve Paxton's 1967 piece Satisfying Lover or Anne Teresa de Keersmaeker's 1982 break-through solo Fase, the latter incorporated a 45-minute compilation of four choreographies of Rainer that a group of dancers performed four times every day in the exhibition spaces. On the other side of the spectrum, then, one could situate Move: Choreographing You (2010), which took place at London's Hayward Gallery. The very title of the event already indicates that it was the visitor's active participation rather than the distanced contemplation of art works that stood central here. An extensive range of installations, objects, and interfaces were devised that, instead of remotely representing a series of historical choreographies and performances, rather invoked their themes and aesthetics, in an attempt to make these tangible by prompting a dynamic engagement with the art works ${ }^{5}$. In 2012, the Centre for Art and Media (ZKM) in Karlsruhe hosted Moments. A History of Performance in 10 Acts, which covered four successive stages that went from setting up the exhibition in collaboration with the artists and in presence of visitors to inviting other artists,

4 Cf. MACEL, Christine and Emma LAVIGNE (Eds.).

Danser sa vie. Art et danse de 1900 à nos jours. Paris: éditions Centre Pompidou, 2011.

5 Cf. ROSENTHAL, Stephanie (Ed.). Move.

Choreographing You. Cambridge, MA and London: MIT

Press, 2011. a filmmaker, and a group of students to mediate and re-activate the exhibited works that were the starting point of the event ${ }^{6}$.

Whether it concerns more direct re-stagings or re-interpretative re-enactments, museums and galleries are shifting their focus from hanging, placing, or installing works in their halls and spaces to offering their grounds as a stage for choreography and performance. The usurpation of this receptive function traditionally fulfilled by theatre venues begs a range of questions: what alternative potentialities does the museum have to offer to artists who consciously choose to show their work there and not in the theatre, which is arguably the more natural habitat of the performing arts? What is the merit of making live performed dance part of an exhibition, and, conversely, what allure resides in reconsidering exhibitions as choreographies that attempt to "move" people? What can the context of museums contribute to dance and how can the practice of choreography inspire to rethink traditional museal conventions? In order to answer these questions, I will focus on re-enactment as a potentially productive research method to probe the possibilities of incorporating dance into the museum. Articulating such a specific understanding of re-enactment, however, requires that we first gauge the broader cultural context that also informs the emergence of choreography within the museum. To this end, I will briefly consider a preceding gulf of re-enactment that was mainly centred on the musealization of historical performance art and subsequently look at the relationships between not only the museum and the theatre, but also between exhibitions and experiments. This will set the stage for a discussion of two exemplary projects that illustrate a creative and reflective use of re-enactment as a research tool that allows choreographers to test out possible convergences between dance as an art form that generally revolves around

6 Cf. GAREIS, Sigrid, Georg SCHÖLLHAMMER, and Peter WEIBEL (Eds.). Moments. A History of Performance in 10 Acts. Karlsruhe: ZKM, 2013. 
performing bodies and the museum as an institution that is typically devoted to displaying objects.

\section{From Resistance to Revival}

Common definitions of live performance describe this practice in terms that are ostensibly antithetical to museal customs. Erika FischerLichte's characteristic claim that "the bodily co-presence of actors and spectators enables and constitutes performance" highlights how performance comprises artworks that are realized by and in front of embodied subjects in the here and now of a specific temporary situation ${ }^{7}$. Attending a performance therefore obviously differs from visiting a museum, where art pieces or other kinds of material are always already available for beholding. At the same time, this physicality and intersubjective encounter as essential aspects of live performance are precisely what in the 1960 s and 1970 s inspired several artists originally coming from the visual arts to start performing and to challenge the unwritten rules of their discipline. Pioneers such as Gina Pane, Allan Kaprow, or VALIE EXPORT, who all played a pivotal role in founding what would come to be identified as "performance art", turned to the medium of performance in order to infuse their work with embodied presence, corporeal tangibility, or the possibility of interaction. These dimensions were not only thought to be foreign to the supposedly sterile environments of museums, but they also defied any easy encapsulation within institutionalized domains ${ }^{8}$.

Authors as Henry Sayre ${ }^{9}$ and Peggy Phelan ${ }^{10}$ have indeed lucidly charted how a great deal of early experimental performance art thrived on an explicit anti-institutional impetus, not

\footnotetext{
7 FISCHER-LICHTE, Erika. The Transformative Power of Performance. A New Aesthetics. JAIN, Saskya Iris (Transl.). London and New York: Routledge, 2006, p. 32.

8 For a succinct account of the emergence of performance art, see "The Art of Performance," part 2 in CARLSON, Marvin. Performance: A Critical Introduction. 2nd edition. London and New York: Routledge, 2004.

9 SAYRE, Henry. The Object of Performance. The American Avant-Garde since 1970. Chicago: The University of Chicago Press, 1989
}

the least because its short-lived existence was believed to provide a welcome antidote to the presumed penchant of museums for material conservation and capitalistic commerce. This oppositional attitude, however, would soon attenuate as artists quickly came to realize that they could not operate in complete isolation from existing institutional frameworks nor from conventional means of representation. Vito Acconci, for instance, mitigated the belief in the unruly nature of live performance when he bluntly stated that "the action might well have been a picture", since "that's the way it was going to be historically preserved anyway" ${ }^{11}$. Reversely, museums and galleries were very much intrigued by this new and potentially reinvigorating movement, even though it was obvious that these performance pieces could only be acquired, collected, or stored by means of secondary resources that unavoidably erode the liveness of their actual enactment.

This common idea that performance documentation only provides a flattened representation of the work has been challenged by scholars such as Amelia Jones ${ }^{12}$ and Philip Auslander ${ }^{13}$ who variously asserted that photographs, videos, or other documents are performative in their own right as they make a call to the beholder to engage imaginatively with the event that lies behind the documentary relic. Nevertheless, a lingering desire to relive these works not only through archival resources but also as concrete and embodied art forms apparently remained present, leading to the phenomenon currently known as "re-enactment". Among the many different kinds of performance re-enactment, certainly not all of them are meant to be staged in the context of museums, but a substantial segment of this newly arising branch of artistic activity does seek to reinvigorate the musealization of

10 PHELAN, Peggy. Unmarked. The Politics of Performance. New York and London: Routledge, 1997.

11 ACCONCI, Vito. "Performance after the Fact". New Observations. no. 95, May-June 1993, p. 31.

12 JONES, Amelia. "Presence in Absentia. Experiencing Performance as Documentation”. Art Journal. vol. 56, no. 4, 1997, pp. 11-18.

13 AUSLANDER, Philip. "The Performativity of Performance Documentation”. PAJ: A Journal of Performance and Art. vol. 28, no. 3, 2006, pp. 1-10. 
performance art by re-enacting it live. Pivotal in this regard has been Marina Abramovićs largescale project Seven Easy Pieces (Guggenheim, 2005) as well as her retrospective The Artist is Present (MoMa, 2010). In both cases she turned to re-enactment precisely because, in her opinion, "the only real way to document a performance art piece is to re-perform the piece itself" ${ }^{14}$.

However, as Mechtild Widrich points out, Abramović has also been vigorously criticized "for her insistence on charismatic 'presence,' in which some see only a capitalist star system" ${ }^{15}$. In this sense, Abramović's use of re-enactment to make her own persona "present" in some of the world's leading art institutions reveals how easily the practice of re-enacting historical performance works becomes a clever marketing strategy that promises a captivating experience of, or sometimes an active participation in, live performance turned into spectacle, which hopefully attracts new audiences to the museum. As such, re-enactment seems to correspond to a more general change in museum culture that Sabine Breitwieser describes as follows:

The introduction of performance and participative formats in the museum has coincided with a shift from its original conception as a place in which to store, conserve and mediate information about cultural artefacts, towards an audienceoriented approach, in which the museum becomes a service provider within a feelgood, event-oriented culture ${ }^{16}$.

This slippery risk is something to give due consideration with regard to the fact that re-enactment is increasingly being used as a

14 ABRAMOVIĆ, Marina. "Reenactment: Introduction". In. Seven Easy Pieces. Milan: Edizioni Charta, p. 11.

15 WIDRICH, Mechtild. "Is the 'Re' in Re-enactment the 'Re' in Re-performance?" In. DERTNIG, Carola and Felicitas THUN-HOHENSTEIN (Eds.). Performing the Sentence. Research and Teaching in Performative Fine Arts. Berlin: Sternberg Press, 2014, p. 142.

16 BREITWIESER, Sabine. "Taking Part in the Museum". Afterall: A Journal of Art, Context, and Enquiry. no. 34, 2013, p. 9. means to also bring dance into the museum. At a recent panel discussion in New York, Jenny Schlenzka (who is associate curator at MoMa PS1) claimed that "Last year we were arguing about re-performance. This year we're arguing about dance" ${ }^{17}$. To a certain extent, Schlenzka is right that the latest offspring of the tendency to re-enact performance art has shifted the focus to dance. Yet, to be entirely accurate, it should be noted that re-enactment is anything but new in the field of dance. Already in the early 1990s and thus years before performance artists became interested in re-enacting earlier works, several choreographers were actively advancing re-enactment as a new way of re-inventing the history of dance, even if the term as such was not widely used yet. Trailblazing in this regard was, for instance, the work of the French collective Quatuor Albrecht Knust, which returned to existing notations or descriptions of pieces created by Doris Humphrey, Kurt Jooss, Steve Paxton, Yvonne Rainer, or Vasilav Nijinsky, bringing their legacy back to life in a manner that did not shy away from altering the originals ${ }^{18}$.

The fact that re-enactment made an earlier entrance in the domain of choreography should not surprise, given that re-stagings or reprises are after all quite common practice in artistic dance, primarily as a means to keep choreographic repertoires alive. Performance art, on the other hand, has always been considerably more reluctant to the idea of re-doing existing pieces. Precisely because it grew out of a reaction against the visual arts and the predominant focus on creating art objects, the early generation of performance artists in particular attached great importance to the wilfully transient nature of their work, in so far as it was supposed to take place in the

17 Cited in MATTOCKS, Aaron. Performance at the Beginning of the Twenty-First Century. 'http://theperformanceclub.org/wordpress/wp-content/uploads/2012/10/ DanceattheMuseum.pdf' (retrieved in September, 2014). 18 For a brief overview of the work of the collective Quatuor Albrecht Knust and a discussion of its importance for the emergence of re-enactment, see LAUNAY, Isabelle. "Poétiques de la citation en danse. d'un faune (éclats) du Quatuor Albrecht Knust, avant-après 2000”. In. LAUNAY, Isabelle and Sylviane PAGÈS (Eds.). Mémoires et histoires en danse. Paris: L'Harmattan, 2010, pp. 23-72. 
"here and now" of a given time and a certain place. This does not mean, however, that performance art pieces were never "re-staged" or done more than once ${ }^{19}$, but it does mark a crucial difference with other art forms, such as dance or theatre, that, as Amelia Jones writes, have "always acknowledged their reliance on the script that passes down through time to be 'redone"”20.

Despite the divergent historical background of dance and performance art, there is no doubt that, in both areas, artists have been "discovering" re-enactment as one of the most promising formats to secure the afterlife of their discipline. Moreover, even though choreographic re-enactments are not unprecedented, what does distinguish its current upsurge is, quite simply, that the museum is now the privileged host. Therefore, in regard of Breitwieser's suggestion that museums are currently embracing performative practices in order to increase the experiential engagement of their visitors, we need to ask to what extent dance re-enactment might be able to supersede the sheer purpose of diverting the public. One way to tackle this issue and to consider how the museum is actually apt to replace mere enticement with an incitement to thought and reflection is by looking at the implementation of dance in the museum from an etymological angle.

\section{The Return of Terpsichore}

The roots of the museum, it might be recalled, lie in Ancient Greece. Its etymology derives from the Greek word mouseion, which originally referred to "cult sites devoted

19 To name just one example, Carolee Schneemann performed her seminal piece Interior Scroll first in New York in 1975 and a second time in Colorado in 1977, while also her Meat Joy (1964) was shown both in Paris and New York. 20 JONES, Amelia. “'The Artist is Present'. Artistic Re-enactment and the Impossibility of Presence”. TDR: The Drama Review. vol. 55, no. 1, 2011, p. 20, original emphasis. 21 ABT, Jeffrey. "The Origins of the Public Museum”. In. MACDONALD, Sharon (Ed.). A Companion to Museum Studies. Malden, MA: Blackwell Publishing, 2006, p. 115. to the muses" ${ }^{21}$, the daughters of Zeus and Mnemosyne who were worshipped for giving inspiration to the arts, poetry, history, and science. In its earliest instances, however, the mouseion not only functioned as a place of worship but also as a centre of knowledge where ancient scholars would gather to contemplate and study ${ }^{22}$. Two salient aspects can be derived from this incipient emergence of the museum. First, there is the close association of the spheres of art and the domain of research, exemplifying how in ancient times both were considered to be complementary sides of the same coin called knowledge. Secondly, among the muses who were initially deified in the mouseion, there is one who, in the course of centuries, seems to have lost the privileged position she enjoyed in Greek antiquity. Indeed, it is the muse of dance, Terpsichore, who has been conspicuously absent from the museum in its modern forms, moving instead toward the theatre where she would find a new residence.

Terpsichore's change of place, however, is not as radical as one might suspect, given that the etymology of the word theatre readily reveals a common ground with the functions the museum still fulfils nowadays. As Sruti Bala reminds us, theatre derives from thea-tron, which is "a place of looking", while it is also related to theo-rein, which means "to consider, to speculate, to look at" ${ }^{23}$. Etymologically speaking, the theatre and the museum thus converge in their role of providing a space in which the act of looking is combined with the opportunity for reflection, prompting viewers to make sense out of the sensible. Given this alliance, the specificity of the museum and the reasons why choreographers are ardent to

22 The most famous example is probably the Mouseion of Alexandria, founded around 280 BCE. Here, the association of art and science, worship and research is most tellingly symbolized by the location of the Mouseion in close vicinity to the renowned Library of Alexandria, one of the first places where an immense amount of texts was systematically collected and stored, while also actively consulted, translated, or managed by a community of scholars. Cf. MAC, Leod (Ed.). The Library of Alexandria. Centre of Learning in the Ancient World. London and New York: I.B. Tauris, 2000.

23 BALA, Sruti. "The Entangled Vocabulary of Performance”. Rupkatha Journal. On Interdisciplinary Studies in Humanities. vol. 5, no. 2, 2013, p. 14 
have Terpsichore returning to it must reside elsewhere. Perhaps the key to this question lies therefore not so much in the museum itself, but rather in the practice that is most proper to it: the making of exhibitions. In this regard, Paul Basu and Sharon Macdonald offer an interesting angle. Asserting that "the realms of experiments and exhibitions are perhaps not so distinct", they argue that "contemporary exhibitionary practice is-or should be-also an experimental practice", meaning that it provides "a site for the generation rather than reproduction of knowledge and experience" 24 . In this sense, what primarily differentiates the museum from the theatre is the former's potentiality to host exhibitions envisioned as experiments and to develop creative types of research within a public setting. But how does this experimental exhibition practice take shape and what are the privileged modes to actualize this potential?

Basu and Macdonald take their cue from the "increasing prevalence of 'reflexive' or 'meta-exhibitions"' in museums and galleries that, as the term indicates, seek to incorporate various ways of reflecting on the representational mechanisms that undergird the displaying of the material ${ }^{25}$. Significantly, they relate this heightened attention for the mediality of the museum to what Peter Weibel and Bruno Latour regard as a "performative turn" in museum practice, manifesting itself in "new forms of enactment" in which visitors are given a more active role in engaging with the exhibition ${ }^{26}$. Also Griselda Pollock argues that, by means of experimental exhibitions, "museum work becomes both performativity and performance art”, explaining that:

24 BASU Paul and MACDONALD Sharon (Eds.). Exhibition Experiments. Malden, MA: Blackwell Publishing, 2007, p. 2, emphasis added.

25 Ibid., p. 4.

26 WEIBEL, Peter and LATOUR, Bruno. "Experimenting with Representation”. In. Id., p. 107.

27 POLLOCK, Griselda. 2007. "Un-Framing the Modern: Critical Space/Public Possibility”. In. POLLOCK, Griselda and Joyce ZEMANS (Eds.). Museums after Modernism.

Strategies of Engagement. Malden, MA: Blackwell Publishing, 2007 , p. 30. For a more sustained analysis on the performativity of art and exhibitions, see VON HANTELMANN, Dorothea. How to Do Things With Art. Zurich: JRP/Ringier, 2007.
It changes the concept of the public so that they become participants in a cultural activity that is both a creation of involvement and the manufacture of the necessary distance of critical reflection and self-consciousness ${ }^{27}$.

These considerations demonstrate that at the heart of the conjunction of exhibitions and experiments lies the intention to induce both a reflective attitude and an experiential engagement on the part of the visitor, for which performance as well as participation appear to provide the most favourable avenues. However, the difficulty to attain such a precarious balance between knowledge and affect is, as suggested earlier, one of the major problems in the attempt to augment the experimental and performative nature of the museum. Claire Bishop, for instance, identifies what she calls a "laboratory' paradigm" in curatorial practices and critically contends that "in this context, project-based works-in-progress and artists-in-residence begin to dovetail with an "experience economy" in which creative experiments serve the need for continuous renewal and personal enrichment ${ }^{28}$.

Bishop has been at the forefront of a growing scholarly discourse that wants to come to terms with the manner in which art and its institutions can develop modes of participation and models of performance without reducing visitors or spectators to docile cohorts of people allegedly keen to undergo immersive experiences and wary of too much thought ${ }^{29}$. Recent analyses offered by Shannon Jackson ${ }^{30}$, Nicola Shaughnessy ${ }^{31}$, and Jenne Harvie ${ }^{32}$ all examine to what extent artistically inspired

28 BISHOP, Claire. "Antagonism and Relational Aesthetics.” October. no. 110, 2004, p. 52. Cf. FÄRBER, Alexa. "Exposing Expo: Exhibition Entrepreneurship and Experimental Reflexivity in Late Modernity”. In. BASU and MACDONALD, op. cit., pp. 219-239.

29 Cf. BISHOP, Claire. Artificial Hells. Participatory Art and the Politics of Spectatorship. London: Verso, 2012.

30 JACKSON, Shannon. Social Works: Performing Art, Supporting Publics. New York and London: Routledge, 2011. 31 SHAUGHNESSY, Nicola. Applying Performance: Live Art, Socially Engaged Theatre and Affective Practice. Houndmills: Palgrave Macmillan, 2012.

32 HARVIE, Jen. Fair Play. Art, Performance and Neoliberalism. Houndmills: Palgrave Macmillan, 2013. 
experiments, both in and beyond exhibitions and museums, are aimed at activating social groups and public spaces, but often on the verge of relapsing into mere entertainment without added value. Consequently, one of the recurrent questions in these debates is whether institutions such as the museum can ever become truly experimental in nature or whether their apparent interest in open-ended and performative modes of presentation only taps into the presumed needs of contemporary audiences, thereby attenuating the progressive orientation (politically, socially, and artistically) of the exploratory practices they proclaim to embrace.

In spite of the inherent difficulties of aligning the intentions behind experimental exhibitionary practices with the institutional frameworks on which such projects generally depend, taking into account the semantically related meanings of not only the museum and the theatre, but also of exhibitions and experiments, the endeavour to merge them into a cross-disciplinary practice does seem to offer a fruitful ground for a genuine combination of affective appeal and reflective involvement. This, it can be surmised, is also the primary reason why contemporary choreographers are increasingly attracted to explore both the possibilities and the limits of presenting their work in the context of museums, where spectators turn into visitors and where the line between stage and audience is deliberately crossed. Yet, while these observations help to explain Terpsichore's re-appearance in the museum, the question remains as to how the renewed alliances between choreography and the museum can shed another light on the role that performance and participation may play in reinvigorating the spectatorial relationship with museal exhibitions that strive to exceed the level of mere representation by developing more processual formats. Let us therefore look at some of the implications and concrete outcomes of the attempt to incorporate dance in the museum.

33 Cf. GORE, Georgiana, Laurence LOUPPE, and Wilfride PIOLLET. "France. Effervescence and Tradition in French Dance”. In. GRAU, Andrée and Stephanie JORDAN (Eds.).

\section{Dance Inc.}

The very idea of dance's incorporation in the museum already highlights the double nature of this endeavour. Not only does it imply an attempt at in-corpo-ration, understood as bringing the dancing body into an environment traditionally concerned with the displaying of inanimate objects. But it also touches upon the museum as an incorporated business that needs to fulfil its public and educational functions by providing a certain service to its audiences. To incorporate choreography is therefore never entirely devoid of the underlying concerns that are at the core of the museum as an incorporation. However, the manner in which choreographers are approaching the institutionalized area of museal practices shows how they are acutely aware of the laws and customs that govern this field. Consequently, the intrusion of dance into the museum can challenge its established conventions and instantiate a reflective and experimental exhibitionary practice that functions as a form of artistic research into the musealization of dance.

To substantiate this claim, I want to discuss two recent projects of Boris Charmatz and Xavier Le Roy, two French choreographers who each had a tremendous influence in paving the way for a more experimentally orientated dance practice in a country where the idea of continuity and the wish to maintain a stable dance tradition remain very vivid up until today, both institutionally and artistically ${ }^{33}$. Precisely the local as well as the personal background of Boris Charmatz and Xavier Le Roy makes it all the more significant that they both have shown a remarkable interest in the museum as a newly discovered arena where to present their work. Given their shared critical stance toward the artistic ossification to which the institutionalization of dance in France has led as well as their counter-reaction to develop cutting-edge choreographies that do away with the prevalent emphasis on technical virtuosity and easily digestible aesthetics, it would be

Europe Dancing. Perspectives on Theatre Dance and Cultural Identity. London and New York: Routledge, 2000, pp. 28-47. 
expected that they keep far removed from the cultural establishment to which the museum also belongs. It is clear, however, that the motive behind Charmatz and Le Roy's turn to the museum is to re-invent its conventions of representation, audience address, and visitor engagement through a confrontation with the predicaments of their own practice. Whereas Charmatz ventures to re-imagine the institution of the museum as such, Le Roy is concerned with adapting the format of the retrospective in accordance with his own choreographic poetics. Each, in their own manner, open up exemplary pathways that demonstrate how the museum can be turned into a place of active and reflective commemoration instead of being a space exclusively devoted to distanced beholding and material preservation.

\section{Musée de la danse - When Boris Charmatz} was appointed in 2009 as the new director of the Centre chorégraphique national (CCN) of Rennes and Brittany, he only accepted this position when he could overturn its workings and transform it into what he, perhaps provocatively, called a "Museum of Dance". In France, the dance scene is to a large extent structured around a network of nineteen CCNs that were established between the mid-1980s and the early $1990 \mathrm{~s}^{34}$. These CCNs are local institutions that receive governmental funding in order to stimulate both the production and distribution of artistic choreography throughout the country, in addition to providing the necessary infrastructure for artist's residencies and dance classes. While each CCN is led by a choreographer whose task it is to guide and guarantee the artistic policy of the organization, their dependence on political and financial support has not always fostered aesthetic and critical innovations. On the contrary, in 1997, the CCNs were accused of artistic sclerosis and traditionalism by a group of

34 For a recent analysis of the current structure of the French dance scene in terms of financial and political support, see GERMAIN-THOMAS, Patrick. "The Subsidized Contemporary Dance Market in France: Creation at All Costs". International Journal of Arts Management. vol. 15, no. 3, pp. 39-52. See also ORVOINE, Dominique (Ed.). L'Art en présence. Les centres chorégraphiques nationaux, lieux ressources pour la danse. Belfort: ACCN, 2006. nearly 50 choreographers-Boris Charmatz included-who united in a faction called "Les signataires du 20 aôut" with the aim to denounce the structural shortcomings of the situation for contemporary dance in France to the government ${ }^{35}$.

Against this background, Charmatz's decision twelve years later to become the director of a CCN and to rename it Musée de la danse indicates how he intends to work with the existing institutional framework but only to radically reconceive its basic principles. Rather than continuing the relatively prescribed functions of the CCNs, his "Museum of Dance" would, above anything else, become a flexible and creative program, devoted to developing new formats of creation and presentation that, instead of moulding dance into static models, are in line with the fluid, exploratory, and corporeal qualities of contemporary choreography. In addition, the change of name can of course be read as a critique on the notorious absence of dance from the museum, while it also raised the issue whether and in what forms choreography could ever become musealized as a means of defying its typically fleeting nature and securing its history.

In true avant-gardist fashion, Charmatz started his mandate by publishing a manifesto that was not only aimed at reasserting his vanguard position in the field, but also at articulating his intentions and objectives to found a Musée de la danse. In this text, he proclaims that the momentum has come to re-include Terpsichore into the panoply of the museum in a manner that does justice to the nature of her being. "We are at a time in history," he writes, "where a museum can modify BOTH preconceived ideas about museums AND one's ideas about dance" ${ }^{36}$. For Charmatz, to pursue a genuine merging of the museum and dance means to

35 Cf. ROUX, Céline. Danse(s) Performative(s). Enjeux et développements dans le champ chorégraphique français (19932003). Paris: L'Harmattan, pp. 62-69.

36 CHARMATZ, Boris. "Manifesto For a Dancing Museum”, p. 2-3, 'http://www.borischarmatz.org/sites/ borischarmatz.org/files/images/manifesto_dancing museum100401.pdf' (retrieved in October, 2014), original emphasis. 
unsettle the mutually reinforcing assumptions that museums are only about conserving endurable objects and that dances only exist as ephemeral performances enacted by bodies. It is therefore not sufficient just to literally bring dance into the museum as a side-feature that complements traditional modes of exhibition. This would only bolster what Céline Roux condemns as "the non-problematization of the question of the exposition of dance in the French field", where the intrusion of choreography in the museum is often limited to mere "events with dancers" that "overexpose the distinction between the two spheres" rather than bridging their separation ${ }^{37}$. Instead, the important contribution of Charmatz's Musée de la danse consists, according to Roux, in its simultaneous reliance on and displacement of the institutional structures of the museum, which makes his re-invention "replete with paradoxes that render it reflective" 38 .

The reflective side discerned by Roux is also intimated by Charmatz when he writes in his manifesto that the museum of dance can only be realized when we "first forget the image of a traditional museum" and allow it to be a "space [that] is firstly a mental one"39. But what does it mean to consider the museum as a mental space and how can a certain degree of reflectivity be ascribed to it? Zooming in on one of the on-going projects that Boris Charmatz has initiated in order to lay the foundations of his Musée de la danse may help to answer this question. Inviting artists, critics, and scholars, Charmatz has been organizing a series of gatheringsor perhaps "happenings" would be a more suitable term - that all went under the title of Expo Zéro ${ }^{40}$. Central to these meetings was

37 ROUX, Céline. "De l'imprévisble dans le champ chorégraphique ou la pratique de l'écart: le musée de la danse". "http://www.museedeladanse.org/system/article/attachments/documents/162/original_pp-cc-4.pdf?1384941284' (retrieved in October, 2014), own translation.

38 Ibid.

39 CHARMATZ, op. cit., p. 3, emphasis added.

40 Up to date, Expo Zéro had halts in Rennes (2009),

St-Nazaire (2009), Singapore (2009), Utrecht (2010), and New York (2011).

41 The different episodes of Expo Zéro are singular and temporary events, but their afterlife and dissemination is ensured by means of a bilingual website that comprises both the question how each of the invitees would imagine their own museum of dance. The general idea behind it was, quite literally, to go to the zero point of an exposition and to build it up from scratch, using the suggestions and proposals of the participants as the main ingredients to compose a tentative and temporary assemblage that explores what a museum of dance could look like. Before becoming a public event, Expo Zéro functions as a think-tank in which people reflect on what it might meannot only for them, but also for the audience- to envision dance as a museum. Whatever comes out of these sessions, then, furnishes the proverbial building blocks with which the eventual yet transient exposition is erected ${ }^{41}$.

Communal reflection is therefore part and parcel of how Boris Charmatz imagines the museum of dance and which explains why he primarily conceives of it as a "mental" space. Yet this mental space also extends to certain preconceptions about the museum and changing these requires that visitors too are involved in the act of questioning of them. For this reason, when Expo Zéro opens its doors, the event is as much about dancing as about talking, with the "works" on display ranging from the re-enactment of choreographic phrases during which the performers explain the provenance of the steps or talk about the effort demanded to execute them; to workshop formats in which visitors are invited to try out dance techniques such as contact improvisation; to installations that combine text with image in a reflection on the conditions of musealizing dance. Thus, as Gilles Almavi describes the project, "discourse, performance: one can say that Expo Zéro is thought no less than

an online catalogue consisting of various texts written by the participants and the possibility to take an virtual and interactive tour through the exposition. Especially the latter reflects astutely well the open structure of the actual Expo Zéro, since it invites its visitors to navigate through it by choosing between different threads and pathways, much like the audience of the "real" expositions is not guided through a preconceived trajectory but instead given the opportunity to explore the various parts autonomously. Cf. 'http://expozero. museedeladanse.org' (retrieved in October, 2014). 
un-thought” ${ }^{42}$. Unthinking in terms of undoing standard exhibition formats, but rethinking by envisioning them anew. Unthinking as a means of giving movement and dance a central and autonomous place in this museal environment, but rethinking by overlaying these bodily acts with discursive asides in order to articulate the meaning of the various interventions. Performance and participation are reflectively framed insofar as they stand in service of imagining a museum of dance rather than serving to allure the public.

While Expo Zéro is not the only project that goes under the banner of the Musée de la danse ${ }^{43}$, it does exemplify how Boris Charmatz conceives of "his" museum as a fluid framework that does not impose any pre-given ideas on what it should be, but rather focuses on what it can become. Pursuing what Charmatz calls "a policy of provocative profusion" ${ }^{\prime 4}$, this dance museum is a continuous work-in-progress that involves a variety of participants who each give shape to its eventual and multifarious incarnations. In this context, re-enactment becomes one tool among others that not only allows to revivify dance but also to test, replace, and even dissolve the boundaries of the museum by showing how museal preservation is an effect of the thinking and moving bodies that actively engage in it. Experiment or exhibition, museum or theatre, Expo Zéro incorporates them all in order to instantiate an ongoing and collaborative research program on what a museum of/as dance could entail.

\section{Rétrospective - The intention of Boris}

Charmatz to (re)move the boundaries of the museum by turning it into a flexible, nomadic, and also mental structure can be usefully compared with Xavier Le Roy's attempt to push his choreographic practice not so much beyond but rather into the museum. The impulse for

42 ALMAVI, Gilles. "Expo Zéro". 'http://www.

museedeladanse.org/fr/articles/expo-zero-par-gilles-amalvi' (retrieved in October, 2014).

43 The website of Musée de la danse provides a detailed overview of the different projects that were and are being conducted under its name. Cf. 'http://www.museedeladanse. org/fr' (retrieved in October, 2014).

44 CHARMATZ, op.cit., p. 3. this came from Laurence Rassel, the artistic director of the Antoni Tàpies Foundation in Barcelona (Spain), who in 2012 invited Le Roy to present his work in their exhibition halls, giving him-as Le Roy explains in an interview- "what she called carte blanche" and asking him to "do something, whatever [he] want[ed]" ${ }^{45}$. Intrigued by the challenge to adapt his dance works to the specific spatial demands and modes of watching that adhere to a museal setting, Le Roy created his Rétrospective, a deceitful title for an exhibition that decidedly refuses to be anything commonly associated with a retrospective. Ultimately, even if the focus lies on live performing arts, prevailing conventions can be maintained. Marina Abramović's The Artist is Present, for example, provided a chronological overview of her artistic oeuvre by means of a fairly traditional set-up consisting of videos and documents, complemented by the allegedly "innovative" element of juxtaposing these materials with live re-enactments by a cast of young performers. Xavier Le Roy, in contrast, chose to ascribe a less central role to documentary exhibits and to experiment more playfully with different forms of re-enactment as the core strategy for the so-called retrospect on his career as a choreographer.

The source material on which the exhibition draws consists mainly of the solo works Le Roy created between 1994 and 2010, but none of these pieces are shown integrally and neither are they necessarily all presented. For each edition of Rétrospective ${ }^{46}$, Le Roy selects a different troupe of performers and it depends on their individual preferences which solos become part of the exhibition. Le Roy neither requires his dancers to produce literal copies of the original choreographies, asking them instead to appropriate the material in accordance with the characteristic features of their

45 LE ROY, Xavier. Interview by Will RAWLS. Movement Research, 13 November 2014, http://www.movementresearch.org/criticalcorrespondence/blog/?p=9465 (retrieved in March, 2015).

46 After its first showing in Barcelona, Rétrospective has also been presented in Rennes (2012), Salvador (2012), Hamburg (2013), Rio de Janeiro (2013), Paris (2014), Singapore (2014), and New York (2014). 
own bodily constitution as well as their personal histories in order to arrive at what he calls "their individual retrospective" ${ }^{37}$. While the "content" of Rétrospective is therefore inherently variable and always fluctuating, its formal structure remains relatively stable. Le Roy chose immobility, the loop, and narrative as the three main representational modes in which the heterogeneous material is couched and which shape the viewer's experience accordingly. Entering the exhibition, visitors encounter dancers citing fragments from Le Roy's choreographies by holding a still pose or by repeating phrases in a loop. Proceeding further, some of the dancers interrupt their act and start to ask whether visitors want to hear which part of Le Roy's solos is their favourite one or how it was to go through the process of re-embodying these pieces. To those willing to listen, they begin to tell individual anecdotes on their experience of being part of the retrospective.

Le Roy's three-pronged approach illustrates his intention to mingle different disciplinary conventions. While immobility shows dancers holding a gesture in suspension that gives them a statue-like quality, the idea of the loop is rather reminiscent of the serial repetition that is often found in video and installation art. The narrative format, in turn, evokes a more theatrical situation by engaging visitors in a storyline (whether fictional or real) that recounts how the dancers perceive their participation in the exhibition as a whole. What conjoins these representational principles is that each functions as a specific kind of re-enactment that, whether through gestural citation or spoken words, looks back on the past by trying to echo it rather than by offering a full reconstitution. Even if Le Roy claims that he

47 LE ROY, Xavier. "'Montrer ce qui est vivant”. Agôn, Dossiers, No. 6: La Reprise, Dossier artistique/Rétrospective. 'http://agon.ens-lyon.fr/index.php?id=2749' (retrieved in October, 2014), own translation.

48 Ibid. is not interested in the notion of "reprise" and regards his work primarily as a continuous "recycling" of previous ideas or choreographic material ${ }^{48}$, his Rétrospective is an exemplary instance of re-enactment employed as a creative and re-interpretative strategy that reflects on the conditions as well as on possible models of historicization. In the case of Le Roy, this reflection takes shape as an exhibition that is citational rather than merely imitative in character, using embodied performance to re-activate memories and to highlight how any act of recollection is by necessity temporal and subjective in nature.

\section{Le Roy's Rétrospective can be regarded as a} clever research project that explores how the museum can house personalized memories of dance rather than its canonized histories ${ }^{49}$. Instead of being a retrospective in the strict sense of the word, Le Roy re-invents the format by approaching it as what he calls a "mode of production", which entails that he and his dancers "are searching to produce something and not to reproduce something" ${ }^{50}$. Such a claim reverberates with Basu and Macdonald's view on exhibitions as experiments that are concerned with generating knowledge rather than simply re-producing it. Along these lines, the broader epistemological significance of Le Roy's Rétrospective resides not so much in its evocation of a recent choreographic past, but rather in its foregrounding of a curatorial procedure that respects the exploratory nature of contemporary dance and succeeds in translating this to a museal setting. This point is also suggested by performance scholar Johannes Birringer, who interprets Le Roy's Rétrospective as "challenging us to connect a body of work to research processes and reinterpretation-as-production", by which he means that it provides

49 It should be noted that Le Roy's unconventional approach does not necessarily attenuate - and actually may become subject to- the museum's institutional power to build a canon by including certain works between its walls while excluding others. At the same time, it can be argued that the flexible, partial, and time-based manner in which Le Roy "exhibits" part of his oeuvre resists to become entirely recuperated by the museum, insofar as he primarily relies on its function to provide a platform for dissemination rather than for consecration. 
"an open cluster of tools that can be used in a generic capacity for both public observation/ analysis and production" ${ }^{51}$. From this perspective, Rétrospective transcends its own particular objectives, becoming an exemplary project that proposes possible strategies to incorporate dance into the museum. While the proximity of the dancers allows visitors to engage affectively with the "works" on display, the unconventional format challenges them to read into the material and to reflect on their actual encounter with these citational memories ${ }^{52}$.

\section{Re-enactment as Research}

Due to the longstanding absence of Terpsichore from the museum, there is a pressing need to examine how exactly she might return to her cradle. Re-enactment is one of the means currently explored to facilitate the renewed convergences between choreography and the museum. Among the manifold forms re-enactment can take, my focus went to those that assume a particularly strategic dimension by being part of a broader critical and creative investigation into the mechanisms that buttress the museal incorporation of dance. While, in this sense, my guiding assumption was that re-enactment can function as a distinct form of research, it is now possible to articulate more clearly the different lines of inquiry at the heart of this practice.

Most basically, re-enactment provides a possibly productive strategy to develop so-called "meta-exhibitions" that self-reflectively frame their endeavour to forge imaginative alliances between dance and the museum. The cases of Boris Charmatz and Xavier Le Roy exemplify various ways in which re-enactment can be put to use (ranging from the demonstration of dance phrases, to the participation in collective choreography classes, to the citation of bodily gestures, to the verbal recounting of memories),

51 BIRRINGER, Johannes. "What Score? Pre-

Choreography and Post-Choreography”. International Journal of Performance Arts \& Digital Media. vol. 9, no. 1, 2013, p. 10. 52 For further discussions of Le Roy's exhibition, see CVEJIĆ, Bojana (Ed.). "Rétrospective" by Xavier Le Roy. Paris: Les presses du réel, 2014. while they both also embed it in a larger constellation that is open-ended and flexible in nature, leaving it up to the visitor to give a certain place to works that, at first sight, appear to be out of place. This enhances the potential of re-enactment to provoke a reflective attitude towards the encounter with dance in a setting that is commonly thought to be incommensurable with it. What this confrontation brings to light, then, are the ingrained conventions pertaining to both spheres, destabilizing one's inhabited modes of watching in order to redefine them.

Being a leverage to bring bodies and performance into the museum, re-enactment aims to activate thought as much as it strives to involve its public affectively, pursuing a genuine combination of knowing and feeling. As such, it may fulfil the promise that Barbara KirshenblattGimblett ascribes to the museum. She writes that:

To think about the museum as an art practice ... is to recognize that art is itself a mode of inquiry, that science is an art, and that the capacity to think is linked to the capacity to feel ${ }^{53}$.

As we have seen, however, to generate knowledge by means of an experientially oriented museal practice is a difficult balance to attain. Ongoing debates on performance, participation, and the concomitant repositioning of museums as laboratories or working spaces all essentially revolve around the question of how the educational and epistemological functions of the museum can be reconciled with the demand to make its contents accessible, if not easily digestible. Complex as these issues are, the manner in which choreographers such as Charmatz and Le Roy are exploring the scope of re-enactment not only by experimenting with participative formats, direct public address, or embodied representations, but also

53 KIRSHENBLATT-GIMBLETT, Barbara. "The Museum - A Refuge for Utopian Thought”. 'http://www.nyu.edu/ classes/bkg/web/museutopia.pdf' (retrieved in October, 2014). 
by framing these as deliberate interventions in museal practices might inspire curatorial strategies that, once the novelty of dance's incorporation in the museum has blown over, can strengthen a sustained association between both domains. The experiences involved in Expo Zéro and Rétrospective are not so much a matter of diverting the public, but rather of providing a closer look into the principles, techniques, poetics, or background that inform the works on display. To this end, both the spatial arrangement and temporal dynamics of the museum provide a more appropriate arena than the theatre.

Apart from the institutional impact of re-enactment in terms of research into the musealization of choreographic practices, there is also the relationship it instigates with the memory of dance. To the degree that the museum's primary task is to provide a site for the preservation as well as representation of a given heritage, it is key in building a cultural memory and, related to this, a sense of community ${ }^{54}$. The museal intrusion of dance by means of re-enactment obviously taps into this function, but it also adds another layer to it. Instead of merely looking back on a past that is in essence irretrievable, it displaces this lingering nostalgia by allowing what Emily Keightley and Michael Pickering theorize as "the mnemonic imagination”. Arguing that memory is always already imaginative in nature, Keightley and Pickering go against the prevalent view that memories should be "true" and expunged from "false" or "fictional" imagination. In their opinion, "memory is mobile and formative, not merely repetitive" and it is only by acknowledging this that we can exploit the most salient feature of recollection, which is "the creative production of meaning about the past, present and future in their various interrelations" 55 . A similar kind of "mnemonic imagination" is what choreographers as Boris Charmatz and Xavier Le Roy bring to the museum: rather than consecrating a bygone past, they imaginatively re-invent it, relying on re-enactment as a

54 Cf. CROOKE, Elizabeth. Museums and Community. Ideas, Issues and Challenges. London and New York: Routledge, 2007. creative means to generate a sensuous engagement with the memory of dance that, at the same time, provides insight in both the setting and the senses it engages with.
55 KEIGHTLEY, Emily and Michael PICKERING. The Mnemonic Imagination. Houndmills: Palgrave Macmillan, 2012, p. 7. 


\section{La reconstitution [reenactment] en tant que méthode de recherche en muséalisation de la danse}

En partant du constat qu'au cours des dernières années l'intérêt d'introduire la danse au musée s'est accru, l'article examine comment la reconstitution devient la forme prédominante pour y parvenir. En redéfinissant la reconstitution en termes de stratégie créative et réinterprétative visant à dépasser le niveau de remise en scène de la danse, l'auteur cherche à démontrer qu'il est possible d'offrir aux chorégraphes contemporains une méthode de recherche particulièrement productive qui sonde les possibilités d'intégration de leur travail au musée. Ces formes expérimentales de reconstitution de la danse sont analysées non seulement en termes de contre-réaction à l'absence prolongée de la chorégraphie au musée, mais aussi en termes des nouvelles possibilités suivant la récente réorientation des pratiques muséales et curatoriales.

En plus de l'attention accrue portée à la performance et à la participation en tant que moyens d'intensification de l'engagement expérientiel des visiteurs au musée, les expositions témoignent aussi d'une autoréflexivité accrue quant aux mécanismes représentationnels qui soutiennent la mise en espace et la scénographie muséales. La littérature grandissante sur ces tendances dans le champ muséologique permet l'articulation de leurs potentialités et de leurs écueils qui ensemble, participent à l'émergence de la reconstitution de la danse dans l'espace muséal. L'étude de deux cas exemplaires démontre les façons possibles d'intégrer la reconstitution dans une recherche artistique élargie sur la convergence de la danse et du musée. Tandis que le Musée de la danse de Boris Charmatz aspire à imaginer à nouveau l'institution muséale comme un tout, la Rétrospective de Xavier Le Roy traite plutôt de l'adaptation du format de cette exposition conformément à sa propre poétique de la chorégraphie. Les deux projets permettent de faire la lumière sur les champs d'étude qui sont au cœur de la reconstitution lorsque considérée en tant que méthode de recherche devant mener à la muséalisation de la danse. Ils réunissent la confrontation des conventions muséales vis-à-vis de la danse, la recherche d'une combinaison authentique d'engagement affectif et de comportement réflexif de la part du visiteur, et la transformation du musée - lieu de consécration - en un espace d'imagination créative et mnémonique. 